\title{
Occurrence and risk factors for Toxoplasma gondii and Neospora caninum in sheep of the Guarapuava region, Paraná, Brazil
}

\author{
Ocorrência e fatores de risco para Toxoplasma gondii e Neospora caninum em ovinos da \\ região de Guarapuava, Paraná, Brasil
}

\author{
Janaina Menegazzo GHELLER ${ }^{1}$; Rafael CARNIEL ${ }^{1}$; Adriano Oliveira de Torres CARRASCO ${ }^{1}$; Meire \\ Christina SEKI ${ }^{1}$
}

${ }^{1}$ Universidade Estadual do Centro Oeste, Departamento de Medicina Veterinária, Guarapuava - Paraná, Brazil

\begin{abstract}
Toxoplasmosis and neosporosis are diseases that may affect production animals and cause significant economic losses. Given the importance of this fact, risk factors and occurrence of antibodies anti-Toxoplasma gondii and anti-Neospora caninum were determined for 81 sheep in seven farms of the Guarapuava region, state of Paraná, Brazil. Indirect fluorescence antibody test (IFAT) showed antibody frequency of $40.74 \%$ for $T$. gondii and $3.70 \%$ for N. caninum. The risk factors evaluated were: for $T$. gondii, direct contact of sheep with cats and for N. caninum, with dogs; abortion in the herd; and access of other animal species to the same water tank used by the sheep. CI (95\%), Odds Ratio, and $p$ value were determined by Fisher Exact Test. No statistical difference was observed between the occurrence of antibodies and risk factors associated with the presence of antibodies against both parasites. It may be stated that the protozoa T. gondii and N. caninum are found in the sheep herds of this region.
\end{abstract}

Keywords: IFAT. Antibodies. Toxoplasma gondii. Neospora caninum.

\begin{abstract}
Resumo
A toxoplasmose e neosporose são doenças que podem afetar os animais de produção causando perdas econômicas significativas. Sabendo disso, foram determinados os fatores de risco e a ocorrência de anticorpos anti-Toxoplasma gondii e anti-Neospora caninum em 81 ovinos de sete propriedades da região de Guarapuava, Paraná, Brasil. A pesquisa de anticorpos foi realizada por meio da Reação de Imunofluorêscencia Indireta (RIFI) e foi observada uma frequência de 40,74\% para T. gondii e de 3,70\% para $N$. caninum. Os fatores de risco pressupostos para ambas as infecções foram: o contato direto dos ovinos com felinos, para $T$. gondii, e com cães para N. caninum, presença de aborto no rebanho e o acesso de outras espécies animais ao mesmo bebedouro dos ovinos. Por meio do Teste Exato de Fisher foram calculados o IC (95\%), Odds ratio e o valor de $p$, os quais não revelaram associação entre a ocorrência de anticorpos e os fatores de riscos analisados. Pode-se afirmar que os protozoários T. gondii e N. caninum estão presentes entre os rebanhos de ovinos dessa região.
\end{abstract}

Palavras-chave: RIFI. Anticorpos. Toxoplasma gondii. Neospora caninum.

Correspondence to:

Meire Christina Seki

Universidade Estadual do Centro Oeste

Rua Simeão Varela de Sá, 3

CEP 85040-080, Guarapuava, PR, Brazil

email: meireseki@hotmail.com

Received: 20/02/2015

Approved: 06/04/2016

\section{Introduction}

In Brazil and in several other regions of the world, commercial sheep production is expanding. Because of that, the health status of the animals, mainly in relation to reproductive aspects, should be a concern, as they may have direct effects on the production and productivity of the herds. Neospora caninum and Toxoplasma gondii belong to the Apicomplexa phylum and are important causes of reproductive failures in cattle and small ruminants (DUBEY; SCHARES, 2011), and toxoplamosis is an important zoonosis (DUBEY et al., 2012).

Toxoplasmosis is asymptomatic in sheep. However, these animals may acquire the infection during pregnancy, developing reproductive problems as abortion, stillbirths, and delivery of weak animals 
(DUBEY, 2009). The most common form of infection is the ingestion of oocysts in foodstuffs and in the environment (DUBEY, 1986).

Similar to $T$. gondii infection, $N$. caninum may also be responsible for reproductive problems in sheep. Vertical transmission is an important route for $N$. caninum infection, with transplacentary transmission being more common in cattle (DUBEY; SCHARES, 2011). Sheep may be infected by the ingestion of oocysts eliminated by dogs, suggesting the possible occurrence of horizontal infection (DUBEY, 2003).

According to the IBGE census of 2010, sheep population in Brazil was 17,380,581 animals, with the state of Paraná showing 613,934 heads (IBGE, 2010), and Guarapuava as the most important sheepproducing region in the state. Therefore, it is important to have information on the health status of the animals in order to prevent diseases and optimize production. The objective of the present study was to detect sheep positive for $T$. gondii and $N$. caninum antibodies in Guarapuava region using indirect fluorescence antibody test (IFAT) and the association between the occurrence and risk factors to which animals were exposed in each farm.

\section{Material and Methods}

Seven farms were selected by convenience in the municipality of Guarapuava, PR. The number of animals in the herds ranged from 45 to 90 heads. In each heard, $10 \%$ of animals between six months to three years of age were selected. Pregnant or lactating females were selected first and sample was complete with males. A total of 81 blood samples were collected been $69(85.19 \%)$ from females, and 12 (14.81\%) from males. Blood samples were centrifuged, and the sera were frozen until analysis.

All farms used the semi-extensive system, keeping the animals in pastures during the day, and feeding them pelleted feed at night.

Samples were analyzed by Imunoteste Toxoplasma gondii and Imunoteste Neospora caninum (Imunodot Diagnósticos Ltda;, Brazil). Secondary antibodies (anti-sheep) and homologous control sera were provided by the manufacturer. Reactions were considered positive when fluorescence was observed at dilution 1:40 (cutoff value determined by the manufacturer).

In order to analyze the risk factors for the infections, a questionnaire was applied at the moment of sample collection. Seropositive results were correlated with risk factors for infection using Fisher Exact Test and Chi-Square Test in Microsoft Excel, at a $95 \%$ confidence interval.

\section{Results and Discussion}

Six of the eleven (85.71\%) farms presented at least one animal positive for $T$. gondii infection, and three (42.86\%) farms presented at least one animal positive for $N$. caninum. From all the farms analyzed, only one (14.29\%) showed herds free of both infections. The high frequency of seropositivity for $T$. gondii suggests that the infection was spread between herds. Among the 81 samples tested, $33(40.74 \%)$ were positive to $T$. gondii and three (3.70\%) to N. caninum.

$T$. gondii occurrence was in the range observed in studies from the same state, Paraná, which ranged from 7 to $54.6 \%$ (ROMANELLI et al., 2007). This finding demonstrates that the infection is still found in the region. According to Dubey et al. (2012), up to 59\% of sheep surveyed in Brazil had T. gondii antibodies, and viable parasites were isolated from some of their tissues. The center-western region of Paraná is an important region in Brazilian sheep production, with large meat production. Therefore, epidemiological surveys should be carried out in order to demonstrate the actual risk of $T$. gondii transmission by the meat of infected sheep.

For N. caninum, the $3.70 \%$ seropositivity found in the present study was lower than the $9.5 \%$ reported by Romanelli et al. (2007) also in Guarapuava. However, Dubey and Schares (2011) reported that in spite of the economic, clinical, and epidemiologic importance of $N$. caninum, infection in sheep remains uncertain once serological surveys indicate a very low $(0.6 \%$ in New 
Zealand) to high (30.8\% in Brazil) prevalence in asymptomatic sheep.

The analyses of the questionnaires were associated with risk factors both for $T$. gondii and $N$. caninum (Table 1). For $T$. gondii, there was no association between the occurrence of abortion in the herd and seropositivity, different from the findings of Ogawa et al. (2003) and Carneiro (2006) who showed that presence of abortion was an important risk factor.

Although it is known that one of the routes of $T$. gondii transmission is direct contact with the protozoan oocysts, the presence of cats in the farms did not present association with $T$. gondii occurrence $(\mathrm{p} \geq$ 0.05). Neto et al. (2011), Pereira et al. (2012) and Sakata et al. (2012) also found no association with the presence of cats in the farms and seropositivity. On the other hand, Romanelli et al. (2007) observed that access of cats to feed storage was a risk factor $(p<0.05$;
OR: 1.95).

The access of other animals to the same water tank used by the sheep was not a risk factor for disease spread. Although no statistical difference was observed $(p \geq 0.05), \quad \mathrm{the} \quad \mathrm{a} \mathrm{g} \mathrm{e} \mathrm{nt}$ ma $\mathrm{y}$ ingestion of oocysts in drinking water.

For $N$. caninum (Table 1), the occurrence of abortion in the farms did not present statistical significance $(p \geq 0.05 ; \quad \mathrm{OR}: 0.5)$, Moura et al. (2014), and Romanelli et al. (2007), found no association between reproductive disorders and seropositivity. According Dubey and Schares (2011), occasionally, neosporosis may cause abortion, neonatal mortality, and clinical signs in adult sheep. The presence, in this study, of only three or the seven farms presenting cases of abortion may have led to this negative correlation. 
Table 1 - Univariate analysis of the possible risk factors for Toxoplasma gondii and Neospora caninum infection in sheep in the Guarapuava region - Paraná - from 2011 to 2012

\begin{tabular}{|c|c|c|c|c|c|c|c|c|c|c|}
\hline \multirow[t]{2}{*}{ Variables } & \multicolumn{2}{|c|}{ No. of farms } & \multicolumn{2}{|c|}{$\begin{array}{c}\text { Farms with } \\
\text { seropositive animals }\end{array}$} & \multicolumn{2}{|c|}{ Odds ratio } & \multicolumn{2}{|c|}{$\mathrm{Cl} 95 \%$} & \multicolumn{2}{|r|}{$p$} \\
\hline & T. gondi & N. caninum & T. gondii & N. caninum & T. gondii & N. caninum & T. gondii & N. caninum & T. gondii & N. caninum \\
\hline \multicolumn{11}{|c|}{ Occurrence of abortion in the last } \\
\hline \multicolumn{11}{|l|}{ pregnancy } \\
\hline Yes & 3 & 3 & 3 & 1 & -* & 0.5 & -* & $0.02-11.09$ & 0.350 & 0.659 \\
\hline No & 4 & 4 & 0 & 0 & $-*$ & 1 & -* & - & & \\
\hline \multicolumn{11}{|c|}{ Presence of definitive hosts } \\
\hline Yes & 6 & $7^{1}$ & 5 & 3 & $-*$ & - & -* & - & 0.659 & - \\
\hline No & 1 & 0 & 1 & 0 & $-*$ & - & $-*$ & - & & \\
\hline \multicolumn{11}{|c|}{ Other species using the same water tank } \\
\hline Yes & 4 & 4 & 4 & 2 & $-*$ & 2.0 & -* & $0.09-44.35$ & 0.212 & 0.659 \\
\hline No & 3 & 3 & 2 & 1 & $-*$ & 1 & $-*$ & - & & \\
\hline
\end{tabular}

* As one of the results was zero, it was impossible to calculate Odds Ratio and $\mathrm{Cl}$ 95\%

${ }^{1}$ It was not possible to evaluate this fact as a risk factor, since all farms had dogs 


\section{References}

CARNEIRO, A. C. A. V. Soroepidemiologia da toxoplasmose caprina e ovina no estado de Minas Gerais. 2006. 134 f. Dissertação (Mestrado em Parasitologia) Universidade Federal de Minas Gerais, Belo Horizonte, 2006.

DUBEY, J. P. Toxoplasmosis in sheep - the last 20 years. Veterinary Parasitology, v. 163, n. 1-2, p. 1-14, 2009. doi: http://dx.doi.org/10.1016/j.vetpar.2009.02.026.

DUBEY, J. P. Toxoplasmosis. Journal of the American Veterinary Medical Association, v. 189, n. 2, p.166-170, 1986.

DUBEY, J. P.; LAGO, E. G.; GENNARI, S. M.; SU, C.; JONES, J. L. Toxoplasmosis in humans and animals in Brazil: high prevalence, high burden of disease, and epidemiology. Parasitology, v. 139, n. 11, p. 1375-1424, 2012. doi: http://dx.doi.org/10.1017/S0031182012000765.

DUBEY, J. P.; SCHARES, G. Neosporosis in animals - the last five years. Veterinary Parasitology, v. 180, n. 1, p. 90-108, 2011. doi: http://dx.doi.org/10.1016/j.vetpar.2011.05.031.

DUBEY, J. P. Review of Neospora caninum and neosporosis in animals. The Korean Journal of Parasitology, v. 41, n. 1, p. 1-16, 2003. doi: http://dx.doi.org/10.3347/kjp.2003.41.1.1.

INSTITUTO BRASILEIRO DE GEOGRAFIA E ESTATÍSTICA (IBGE). Produção da Pecuária Municipal. Produção da Pecuária Municipal, v. 38, p. 1-65, 2010. Available from: <http://goo.gl/Pyow2c >. Viewed: 26 May 2015.

MOURA, A. B.; GÜTHS, M. F.; FARIAS, J. A.; SOUZA, A. P.; SARTOR, A. A.; QUADROS, R. M. Neospora caninum seroprevalence and risk factors for ewes from Santa Catarina Plateau, Brazil. Semina: Ciências Agrárias, v. 35, n. 5, p. 2591-2600, 2014. doi: http://dx.doi.org/10.5433/16790359.2014v35n5p2591.
NETO, A. V.; MOURA, A. B.; GÜTHS, M. F.; SOUZA, A. P.; SARTOR, A. A.; BELLATO, V. Soroprevalência e fatores de riscos para infecção por Toxoplasma gondii em ovinos do Planalto Serrano de Santa Catarina. In: CONGRESSO BRASILEIRO DE MEDICINA VETERINÁRIA, 38., Florianópolis. Anais... Florianópolis: CONBRAVET, 2011.

OGAWA, L.; NAVARRO, I. T.; FREIRE, R. L.; OLIVEIRA, R. C.; VIDOTTO, O. Ocorrência de anticorpos antiToxoplasma gondii em ovinos da região de Londrina no estado do Paraná. Semina: Ciências Agrárias, v. 24, n. 1, p. 57-62, 2003. doi: http://dx.doi.org/10.5433/1679-0359.2003v24n1p57.

PEREIRA, M. F.; PEIXOTO, R. M.; LANGONI, H.; GRECA JUNIOR, A.; AZEVEDO, S. S.; PORTO, W. J. N.; MEDEIROS, E. S.; MOTA, R. A. Risk factors for Toxoplasma gondii infection in sheep and goats in Pernambuco, Brazil. Pesquisa Veterinária Brasileira, v. 32, n. 2, p. 140-146, 2012. doi: http://dx.doi.org/10.1590/S0100-736X2012000200009.

ROMANELLI, P. R.; FREIRE, R. L.; VIDOTTO, O.; MARANA, E. R. M.; OGAWA, L.; PAULA, V. S. O.; GARCIA, J. L.; NAVARRO, I. T. Prevalence of Neospora caninum and Toxoplasma gondii in sheep and dogs from Guarapuava farms, Paraná State, Brazil. Research in Veterinary Science, v. 82, n. 2, p. 202-207, 2007. doi: http://dx.doi.org/10.1016/j.rvsc.2006.04.001.

ROSA, L. D.; MOURA, A. B.; GÜTHS, M. F.; BELLATO, V.; SARTOR, A. A.; SOUZA, A. P. Prevalência e fatores de risco para infecção por Neospora caninum em ovinos no município de Lages, Santa Catarina, Brasil. Revista de Ciências Agroveterinárias, v. 10, n. 2, p. 127-137, 2011.

SAKATA, F. B. L. S.; BELLATO, V.; SARTOR, A. A.; MOURA, A. B.; SOUZA, A. P.; FARIAS, J. A. Toxoplasma gondii antibodies sheep in Lages, Santa Catarina, Brazil, and comparison using IFA and ELISA. Revista Brasileira de Parasitologia Veterinária, v. 21, n. 3, p. 196-200, 2012. doi: http://dx.doi.org/ 10.1590/S198429612012000300004. 